\title{
THE NEW MIDDLE AGES
}

\author{
BONNIE WHEELER, Series Editor
}

The New Middle Ages is a series dedicated to pluridisciplinary studies of medieval cultures, with particular emphasis on recuperating women's history and on feminist and gender analyses. This peer-reviewed series includes both scholarly monographs and essay collections.

\section{PUBLISHED BY PALGRAVE:}

Women in the Medieval Islamic World: Power,

Patronage, and Piety

edited by Gavin R. G. Hambly

The Ethics of Nature in the Middle Ages: On

Boccaccio's Poetaphysics

by Gregory B. Stone

Presence and Presentation: Women in the

Chinese Literati Tradition

by Sherry J. Mou

The Lost Love Letters of Heloise and Abelard:

Perceptions of Dialogue in Twelfth-Century

France

by Constant J. Mews

Understanding Scholastic Thought with Foucault by Philipp W. Rosemann

For Her Good Estate: The Life of Elizabeth de Burgh

by Frances A. Underhill

Constructions of Widowhood and Virginity in the Middle Ages

edited by Cindy L. Carlson and Angela Jane Weisl

Motherhood and Mothering in Anglo-Saxon England

by Mary Dockray-Miller

Listening to Heloise: The Voice of a Twelfth-

Century Woman edited by Bonnie Wheeler

The Postcolonial Middle Ages edited by Jeffrey Jerome Cohen

Chaucer's Pardoner and Gender Theory: Bodies of Discourse

by Robert S. Sturges
Crossing the Bridge: Comparative

Essays on Medieval European and

Heian Japanese Women Writers edited by Barbara Stevenson and Cynthia Ho

Engaging Words: The Culture of Reading in the Later Middle Ages

by Laurel Amtower

Robes and Honor: The Medieval World of

Investiture

edited by Stewart Gordon

Representing Rape in Medieval and Early

Modern Literature

edited by Elizabeth Robertson and

Christine M. Rose

Same Sex Love and Desire Among Women in the Middle Ages

edited by Francesca Canadé Sautman and Pamela Sheingorn

Sight and Embodiment in the Middle Ages:

Ocular Desires

by Suzannah Biernoff

Listen, Daughter: The Speculum

Virginum and the Formation of

Religious Women in the

Middle Ages

edited by Constant J. Mews

Science, the Singular, and the Question of

Theology

by Richard A. Lee, Jr.

Gender in Debate from the Early Middle Ages to the Renaissance edited by Thelma S. Fenster and Clare A. Lees 
Malory's Morte Darthur: Remaking Arthurian Tradition

by Catherine Batt

The Vernacular Spirit: Essays on Medieval

Religious Literature edited by Renate Blumenfeld-Kosinski, Duncan Robertson, and Nancy Warren

Popular Piety and Art in the Late Middle Ages: Image Worship and Idolatry in England 1350-1500

by Kathleen Kamerick

Absent Narratives, Manuscript Textuality, and

Literary Structure in Late Medieval England by Elizabeth Scala

Creating Community with Food and Drink in Merovingian Gaul by Bonnie Effros

Representations of Early Byzantine Empresses: Image and Empire by Anne McClanan

Encountering Medieval Textiles and Dress:

Objects, Texts, Images edited by Désirée G. Koslin and Janet Snyder

Eleanor of Aquitaine: Lord and Lady edited by Bonnie Wheeler and John Carmi Parsons

Isabel La Católica, Queen of Castile: Critical Essays edited by David A. Boruchoff

Homoeroticism and Chivalry: Discourses of Male Same-Sex Desire in the Fourteenth Century by Richard Zeikowitz

Portraits of Medieval Women: Family, Marriage, and Politics in England 1225-1350 by Linda E. Mitchell

Eloquent Virgins: From Thecla to Joan of Arc by Maud Burnett McInerney

The Persistence of Medievalism: Narrative Adventures in Contemporary Culture by Angela Jane Weisl
Capetian Women

edited by Kathleen Nolan

Joan of Arc and Spirituality edited by Ann W. Astell and Bonnie Wheeler

The Texture of Society: Medieval Women in the Southern Low Countries edited by Ellen E. Kittell and Mary A. Suydam

Charlemagne's Mustache: And Other Cultural

Clusters of a Dark Age by Paul Edward Dutton

Troubled Vision: Gender, Sexuality, and Sight in Medieval Text and Image edited by Emma Campbell and Robert Mills

Queering Medieval Genres by Tison Pugh

Sacred Place in Early Medieval Neoplatonism by L. Michael Harrington

The Middle Ages at Work edited by Kellie Robertson and Michael Uebel

Chaucer's Jobs by David R. Carlson

Medievalism and Orientalism: Three

Essays on Literature, Architecture, and

Cultural Identity by John M. Ganim

Queer Love in the Middle Ages by Anna Klosowska Roberts

Performing Women: Sex, Gender, and the Medieval Iberian Lyric by Denise K. Filios

Necessary Conjunctions: The Social Self in Medieval England by David Gary Shaw

Visual Culture and the German Middle Ages edited by Kathryn Starkey and Horst Wenzel 
Medieval Paradigms: Essays in Honor of Jeremy duQuesnay Adams, Volumes 1 and 2 edited by Stephanie Hayes-Healy

False Fables and Exemplary Truth: Poetics and Reception of a Medieval Mode by Elizabeth Allen

\section{Ecstatic Transformation \\ by Michael Uebel}

Sacred and Secular in Medieval and Early

Modern Cultures edited by Lawrence Besserman

Tolkien's Modern Middle Ages edited by Jane Chance and Alfred Siewers

Representing Righteous Heathens in Late Medieval England by Frank Grady

Byzantine Dress

by Jennifer Ball

The Laborer's Two Bodies by Kellie Robertson

The Dogaressa of Venice, 1200-1500: Wife and Icon

by Holly S. Hurlburt

Logic, Theology, and Poetry in Boethius, Abelard, and Alan of Lille: Words in the Absence of Things by Eileen Sweeney
The Theology of Work: Peter Damian and the Medieval Religious Renewal Movement by Patricia Ranft

On the Purification of Women: Churching in Northern France, 1100-1500 by Paula Rieder

Writers of the Reign of Henry II: Twelve Essays Edited by Ruth Kennedy and Simon Meecham-Jones

Lonesome Words: The Vocal Poetics of the Old English Lament and the African-American Blues Song by M. G. McGeachy

Music in Medieval English Nunneries:

Performing Piety by Anne Bagnell Yardley

The Flight from Desire: Augustine and Ovid to Chaucer by Robert R. Edwards

Mindful Spirit in Late Medieval Literature: Essays in Honor of Elizabeth D. Kirk edited by Bonnie Wheeler

Women, Power, and Religious Patronage in the Middle Ages by Erin L. Jordan

Hybridity, Identity, and Monstrosity, in Medieval Britain: On Different Middles by Jeremy Jerome Cohen

Medieval Go-Betweens and Chaucer's Pandarus by Gretchen Mieszkowski 



\section{MEDIEVAL GO-BETWEENS AND CHAUCER'S PANDARUS}

Gretchen Mieszkowski 


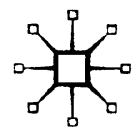

MEDIEVAL GO-BETWEENS AND CHAUCER'S PANDARUS

(C) Gretchen Mieszkowski, 2006.

Softcover reprint of the hardcover 1st edition 2006 978-1-4039-6341-3

All rights reserved. No part of this book may be used or reproduced in any manner whatsoever without written permission except in the case of brief quotations embodied in critical articles or reviews.

First published in 2006 by PALGRAVE MACMILLAN'M

175 Fifth Avenue, New York, N.Y. 10010 and Houndmills, Basingstoke, Hampshire, England RG21 6XS

Companies and representatives throughout the world.

PALGRAVE MACMILLAN is the global academic imprint of the Palgrave Macmillan division of St. Martin's Press, LLC and of Palgrave Macmillan Ltd. Macmillan ${ }^{\circledR}$ is a registered trademark in the United States, United Kingdom and other countries. Palgrave is a registered trademark in the European Union and other countries.

ISBN 978-1-349-73191-6 ISBN 978-1-137-08519-1 (eBook)

DOI 10.1007/978-1-137-08519-1

Library of Congress Cataloging-in-Publication Data

Mieszkowski, Gretchen.

Medieval go-betweens and Chaucer's Pandarus / Gretchen Mieszkowski p. cm.-(New Middle Ages)

Includes bibliographical references and index.

1. Literature, Medieval-History and criticism. 2. Go-betweens in literature. 3. Lust in literature 4. Love in literature. 5. Chaucer, Geoffrey, d. 1400. Troilus and Criseyde. I. Title. II. Series.

PN682.G64M54 2006

$820.9^{\prime} 3538-\mathrm{dc} 22$

A catalogue record for this book is available from the British Library.

Design by Newgen Imaging Systems (P) Ltd., Chennai, India.

First edition: August 2006

10987654321

Transferred to digital printing in 2007. 


$$
\text { For }
$$

Peter, Katharine, and Jan 



\section{CONTENTS}

Part I Choreographing Lust: Go-Betweens for Sexual Conquest

Latin Comedies $\quad 20$

Fabliaux $\quad 38$

The Birth of Heroes $\quad 55$

Four Thirteenth-Century Go-Betweens $\quad 58$

Dame Hiersent: Women as Property 58

Myrrha's Wicked Nurse $\quad 59$

La Vieille: Sex Commodified 61

The Old Woman Who Does Not Go Between 67

Five Fourteenth and Fifteenth-Century

$\begin{array}{ll}\text { Go-Between Stories } & 70\end{array}$

Part II Choreographing Love: Idealized Go-Betweens 79

Conventional Go-Betweens $\quad 84$

Guinevere-Cligés $\quad 84$

Alexandrine-William of Palerne 86

Galehot-The Prose Lancelot 89

Blancheflor's Governess-Tristan 95

Cypriane and Delfin-Florimont 95

Herland-Romance of Horn 100

Glorizia-Boccaccio's Filocolo 105

Pity-René d'Anjou's Le Livre du cuer d'amours 106

Go-Betweens Who Intervene 108

Guinevere-The Prose Lancelot 108

$\begin{array}{ll}\text { Urake-Partonope of Blois } & 109\end{array}$

Lunete-Chrétien de Troyes' Yvain 115 
Claris et Laris

Protheseläus: Dating Romance Going Between

A Go-Between for Lust in an Idealized Story: Éracle

The Two Traditions

Part III Choreographing Lust and Love:

Chaucer's Pandarus

Pandarus as Idealized Friend

Edging Away from Romance

142

Trafficking in Women

146

Il Filostrato

151

Explaining Pandarus via the Romances

155

Becoming Lovers and the Double

Go-Between Tradition

160

Woman: The Most Valuable Gift

175

The Double Go-Between Tradition

179

Notes

185

Bibliography

203

Index 


\section{ACKNOWLEDGMENTS}

This book has been long in the making and would never have come to be without the support of a large number of colleagues, friends, and relatives. It is with great pleasure and heartfelt gratitude that I thank them here.

First I wish to thank Marie Borroff, who read the manuscript of this book when it was twice as long as it now is, and whose insightful advice helped me reconceive it. Bonnie Wheeler's excellent suggestions for major revisions also made this a far better book than it would have been, and her contagious enthusiasm sustained my own faith in it. Laura Hodges advised me on costume issues, contributed invaluable bibliographical material, and generously read and critiqued my manuscript-in-progress not once but twice, while her interest in my go-betweens kept me believing that other Chaucerians might find them of interest. Verva Densmore also critiqued an early very long version of this book. I especially want to thank her and Angela Howard for their unflagging enthusiasm about this project, confidence in my ability to complete it, and sisterly encouragement. Jan and Katharine Mieszkowski gave me expert detailed editing suggestions, and Agatha Whitney helped me admirably with the many secretarial chores a book entails.

I also owe a major debt to Penny Eley (Old French and Anglo-Norman) and Traugott Lawler (medieval Latin) for their creative assistance with my translations. They contributed far more than simply saving me from grammatical pitfalls. Any remaining errors are, of course, my own.

Finally, I wish to acknowledge the assistance of three institutions: the University of Houston-Clear Lake for two semesters of faculty development leave, the American Council of Learned Societies for funding a crucial year of research, and the Mary Ingraham Bunting Institute of the Radcliffe Institute for Advanced Study for providing both access to Harvard's magnificent Widener library during that year and an office in the most supportive feminist environment I have ever experienced.

My debt to Peter, Jan, and Katharine Mieszkowski for their loving support over the years this book has been a part of their lives is inadequately expressed by its dedication. 